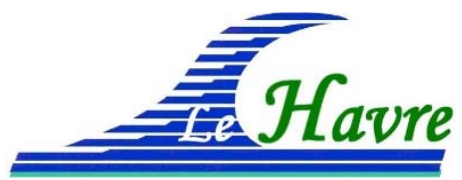

XVI İmes Journées Nationales Génie Côtier - Génie Civil

Le Havre, 2020

DOI:10.5150/jngcgc.2020.055 C Editions Paralia CFL

disponible en ligne - http://www.paralia.fr - available online

\title{
Liquefaction behaviour of unsaturated fine clean sand subjected to cyclic loading
}

\section{Khai Hoan TRAN ${ }^{1,3}$, Saber IMANZADEH ${ }^{2,3}$, Said TAIBI ${ }^{3}$, Hanène SOULI ${ }^{4}$, Jean-Marie FLEUREAU ${ }^{5}$, Mahdia HATTAB ${ }^{6}$}

1. Thai Nguyen University of Technology, Thai Nguyen province, Vietnam.

2. Normandie Univ., INSA Rouen Normandie, Laboratoire de Mécanique de Normandie, 76801 Saint-Etienne du Rouvray, France. saber.imanzadeh@insa-rouen.fr

3. Laboratory UMR CNRS 6294-University of Le Havre Normandy, Le Havre, France. said.taibi@univ-lehavre.fr

4. Laboratory UMR CNRS 5513, Saint Etienne, France. hanene.souli@enise.fr

5. Laboratory MSS-Mat, UMR CNRS 8579, Centrale Supelec, Saclay, Paris, France. jean-marie.fleureau@ecp.fr

6. University of Lorraine, Nancy, France.

mahdia.hattab@univ-lorraine.fr

\begin{abstract}
:
This research study presents the experimental results when the soil samples in a dense state are subjected to cyclic deviator loading. The material used in the tests was RF Hostun sand, a material widely used in the laboratory tests in France. The samples were firstly reconstituted by the moist tamping method and then saturated until achieving the desired saturation degree. The saturation states of the sand were evaluated based on Skempton parameter B. After that, the samples were consolidated and subjected to cyclic deviator stress to study the liquefaction behaviour. The results show that the samples in unsaturated states can be liquefied under cyclic loading and the cyclic shear stress ratio causing liquefaction increases when the saturation degree decreases.
\end{abstract}

Keywords:

RF Hostun sand, Skempton parameter B, Liquefaction, Unsaturation, Cyclic loading.

\section{Introduction}

Soil liquefaction is a phenomenon known for a long time and has caused a lot of damages over the world. The most recent damages due to liquefaction are in the earthquake in Indonesia in 2018 (SASSA et al., 2018) which resulted in significant damages of infrastructures and many casualties. Furthermore, the earthquake in Japan in 2011 and its consequences have made substantial destruction for the nuclear power station due to the tsunami. Some more liquefaction experiences in history can be listed as the 1964 Niigata earthquake; The liquefaction generated by two earthquakes in Turkey in 1999 caused 


\section{Thème 4 - Ouvrages portuaires, offshore et de plaisance}

significant damages to marine structures along the coast of the Izmit Bay. When the soil liquefies, their loss of strength and large deformations can result in failures like flow slides, slope instabilities, building up bending forces on piles and other embedded structures (CHANEY \& PAMUKCU, 1991). From these examples of liquefaction, it can be considered as an aspect of soil behaviour that occurs worldwide and needs to be considered as hazards for structures in coastal.

ISHIHARA (1993) suggested that the term spontaneous liquefaction was coined by Terzaghi and Peck in 1948 although this subject had been known much earlier. Since then, this phenomenon has been studied by many researchers and has achieved some results, especially in the liquefaction behavior of saturated soils CASTRO (1969), SEED \& IDRISS (1982), etc. However, recent studies have demonstrated that liquefaction can be observed not only on saturated soil but also on unsaturated sandy soils. In a study carried out by TSUKAMOTO et al. (2014), they showed that the air bubbles can appear at $5 \mathrm{~m}$ below the groundwater table, it means that most of the building structures are constructed on unsaturated soil layers. MARTIN et al. (1978) in their theoretical study demonstrated the effect of the saturation degree on the cyclic liquefaction resistance of sands. Laboratory tests also have been carried out and revealed the relationship between the saturation degree and the liquefaction susceptibility of sand (CHANEY, 1978; YOSHIMI et al., 1989; FOURIE et al., 2001; TRAN et al., 2018a \& 2018b). MULILIS et al. (1978) investigated the liquefaction of Monterrey sand with the effect of Skempton's coefficient B and they found that the resistance of sand does not change when the value of $B$ is between 0.91 and 0.97 .

Although studies on the liquefaction of unsaturated soils have achieved some progress, it is necessary to have more results to make clear the combined effects with other factors such as initial relative density, effective confining stress, and loading path. This paper presents the results of tests to study the behavior of sand. The first two experiments were carried out on fully saturated samples while the last experiment was performed on unsaturated samples. Through these tests, the influence of saturation degree and different soils fabric caused by sample preparation are studied.

\section{Material and apparatus}

\subsection{Material}

The material is fine quartz sand (RF Hostun) from Sika Co. The sand with its microscope particle shape (BENHAMED, 2001) is shown in figure 1 and the grain size distribution of the material is presented in figure 2 . 


\section{XVİ̀mes Journées Nationales Génie Côtier - Génie Civil \\ Le Havre 2020}

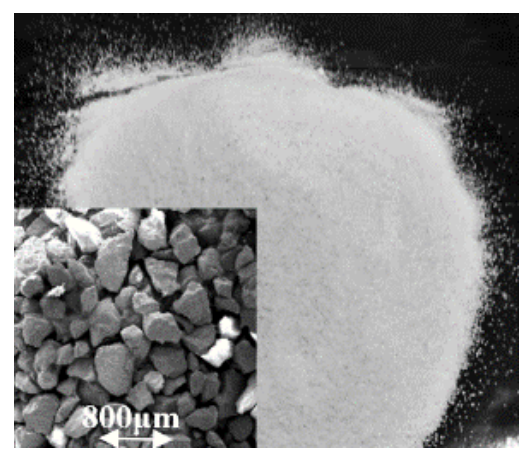

Figure 1. RF Hostun sand.

This material has following parameters: specific gravity $2.65 \mathrm{~g} / \mathrm{cm}^{3}$, maximum grain size $0.6 \mathrm{~mm}$, minimum grain size $0.12 \mathrm{~mm}$. Other parameters are shown in table 1 . Where $\mathrm{D}_{10}$, $\mathrm{D}_{50}, \mathrm{D}_{60}$ are the particle size distributions of RF Hostun sand, e is the initial void ratio of the sample.

Table 1. The parameters of RF Hostun sand.

\begin{tabular}{lllll}
\hline $\boldsymbol{D} 50(\boldsymbol{\mu m})$ & $\boldsymbol{D} 10(\boldsymbol{\mu m})$ & $\boldsymbol{D} 60(\boldsymbol{\mu m})$ & $\boldsymbol{e}_{\max }$ & $\boldsymbol{e}_{\min }$ \\
\hline 300 & 200 & 400 & 1.041 & 0.648 \\
\hline
\end{tabular}

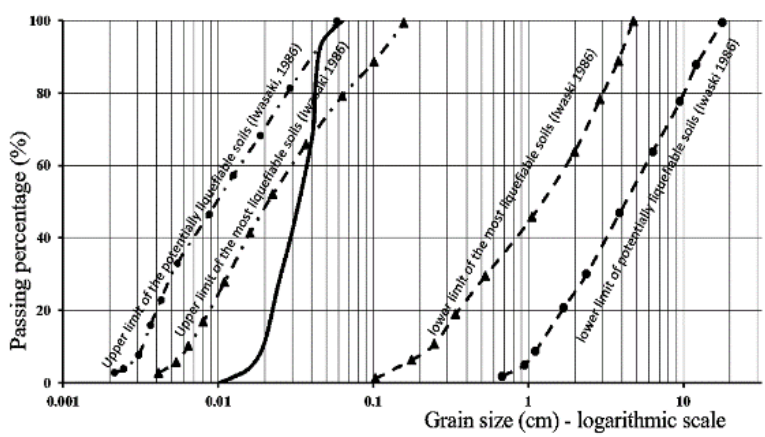

Figure 2. Comparison of grain size distribution of RF Hostun sands to other liquefiable sands (IWASAKI, 1986).

\subsection{Apparatus}

The apparatus used for dynamic tri-axial tests was used in this study (Figure 3). The Dynamic (Cyclic) Triaxial Testing System $5 \mathrm{~Hz} / 5 \mathrm{kN}$ provided by $\mathrm{VJ}$ tech includes a dynamic controller to generate and control dynamic parameters, i.e. force, displacement and pore water pressure. The cell pressure and back pressure are controlled by a Pneumatic Automatic Pressure Control (APC) device and a Hydraulic APC device, respectively. The pressure imposed by the Pneumatic APC is transmitted to the cell through an Air-Water Interface. This device's duty is to make the pressure more responsive and mellifluous, it includes a rubber ball embed in a cell. The pressure generator controls the air pressure inside the rubber ball instead of cell pressure directly. 


\section{Thème 4 - Ouvrages portuaires, offshore et de plaisance}

The specimens used are $70 \mathrm{~mm}$ in diameter and $140 \mathrm{~mm}$ in high. Back pressure is applied on both top and bottom of the sample while the pore water pressure is measured only at the bottom of the sample. The displacement can be controlled by the dynamic controller (this device makes and controls dynamic load) or the axial displacement transducer.

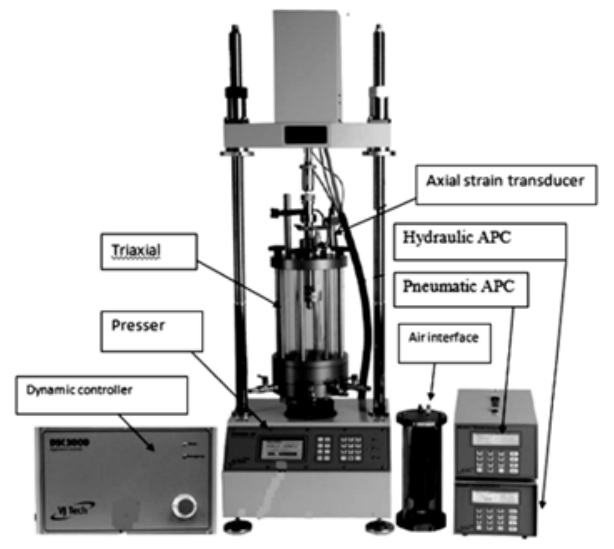

Figure 3. Triaxial dynamic test apparatus.

\section{Test procedure}

\subsection{Sample preparation and sample saturation}

In this study, the samples were prepared by the moist tamping method. This method allows reconstituting the samples with a wide range of relative density. Firstly, the sand was dried and then a fixed quantity of water was added to have a mixture with the initial water content of $8 \%$ and then the mixture was divided into five equal parts. Each part was put in the mold and compacted until reaching the height level calculated based on the desired relative density. The sample size is $70 \mathrm{~mm}$ in diameter and $140 \mathrm{~mm}$ high and initial void ratio of 0.73 . With this void ratio, the relative density is $83 \%$ and the sample is in dense state.

For sample saturation, with the saturated tests, firstly, a cell pressure of $35 \mathrm{kPa}$ had been applied, and then, de-aired water was flushed from the bottom to top until there were not any air bubbles observed in the output pipe. After that, the cell pressure and backpressure were increased slowly to 770 and $750 \mathrm{kPa}$ respectively to dissolve the remaining air in the sample (figure 4). During this process, the effective stress was kept equal to $20 \mathrm{kPa}$. With the unsaturated tests, the unsaturation was imposed by applying two techniques: vacuum using and flushing the sample from bottom to top as being presented for the saturated tests. 


\section{XVI'̀mes Journées Nationales Génie Côtier - Génie Civil \\ Le Havre 2020}

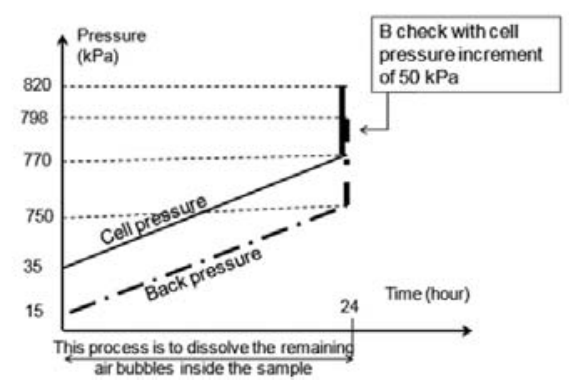

Figure 4. Cell and back pressure enhancement to dissolve the remaining air bubbles inside the sample.

\subsection{Skempton's coefficient B measurement and sample consolidation}

To evaluate the saturation degree, $B$ value was used. The definition of this parameter is the ratio between the measured pore water pressure increase and the imposed cell pressure increase.

$$
B=\frac{\Delta u_{w}}{\Delta \sigma_{3}}
$$

Where $\Delta \sigma_{3}$ and $\Delta u_{w}$ are the imposed increment of confining stress and the resulting measured increment of pore water pressure, respectively.

Because water is incompressible compared to the soils skeleton, the sample is considered to be fully saturated if $B=1$. The appearance of air bubbles with their compressibility makes smaller B value. In practice, a B between 0.95 and 0.97 is regarded as a signal to indicate full saturation of sandy soils due to some compliance in the test apparatus and sample compressibility (CHANEY, 1978; JEFFERIES \& BEEN, 2016). With RF Hostun sand, the $B=0.97$ is achieved in our laboratory when the sample is fully saturated. This value was also used by BENAHMED (2001) and ARAB et al. (2016) for RF Hostun sand as an indication of full saturation state. After that all the samples were consolidated under the effective consolidation pressure of $100 \mathrm{kPa}$.

\subsection{Dynamic deviator loading}

The saw teeth form load with a frequency of $0.1 \mathrm{~Hz}$ and 100 cycles were applied to the top of the sample under un-drained condition. With this frequency, it took ten seconds to finish a cycle of load (figure 5).

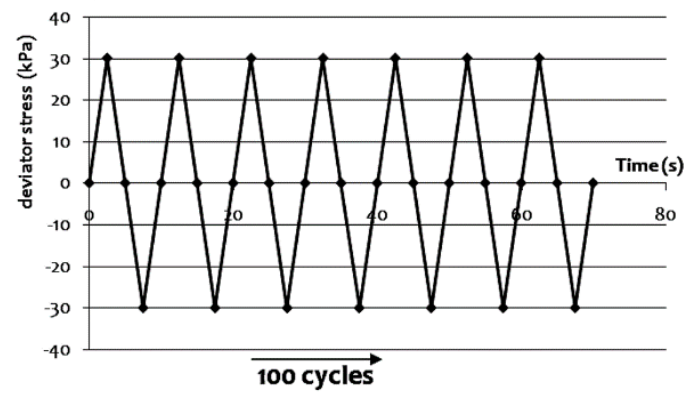

Figure 5. Cyclic deviator stress with CSR $=0.15$. 


\section{Thème 4 - Ouvrages portuaires, offshore et de plaisance}

The amplitude of the deviator stress was chosen initially to be $30 \mathrm{kPa}$ corresponding to a cyclic stress ratio of 0.15 (load case 1). Cyclic stress ratio (CSR) is defined by the following equation:

$C S R=\frac{q_{\max }^{c}}{2 \sigma_{3 c}^{\prime}}$

Where $q_{\max }^{c} / 2$ is the maximum cyclic shear stress, $q_{\max }^{c}$ is the amplitude of deviator dynamic stress. $\sigma_{3 c}^{\prime}$ is the effective consolidation stress.

After 100 cycles of the first cyclic load case, if the sample is still not liquefied the amplitude of cyclic deviator stress $q_{\max }^{c}$ will be increased to have CSR of 0.2 (load case 2), 0.25 (load case 3), and 0.3 (load case 4). In case the sample shows the tendency of liquefaction, the test will continue with unchanged CSR, so the number of cycles of the final load case may be greater than 100 (test 1).

Table 2. Test information.

\begin{tabular}{cccc}
\hline Test & $\boldsymbol{B}$ & Dr & Maximal CSR \\
\hline Test 1 & 0.97 & $79 \%$ & 0.25 \\
\hline Test 2 & 0.7 & $79 \%$ & 0.3
\end{tabular}

Dr: relative density, B: Skempton's coefficient B, CSR: Cyclic Stress Ratio.

\section{Results}

Figure 6 shows the relationship between axial strain and deviator stress of all tests. In figure $6 \mathrm{a}$, the full saturated sample was liquefied by load case 3 with CSR $=0.25$ corresponding to $\mathrm{q}_{\max }=50 \mathrm{kPa}$. When the sample liquefies, its strength decreases and finally the deviator stress fluctuates between $-22 \mathrm{kPa}$ and $39 \mathrm{kPa}$ while the axial strain varies between $0 \%$ and $1.7 \%$. With the unsaturated sample (figure $6 \mathrm{~b}$ ), the deviator stress initially alternates between $-50 \mathrm{kPa}$ and $60 \mathrm{kPa}$ corresponding to CSR of 0.3 . Due to the increase of pore water pressure, the deviator stress decreases and lastly varies from -30 $\mathrm{kPa}$ to $40 \mathrm{kPa}$. The axial strain finally fluctuates between $0.15 \%$ and $2.4 \%$.
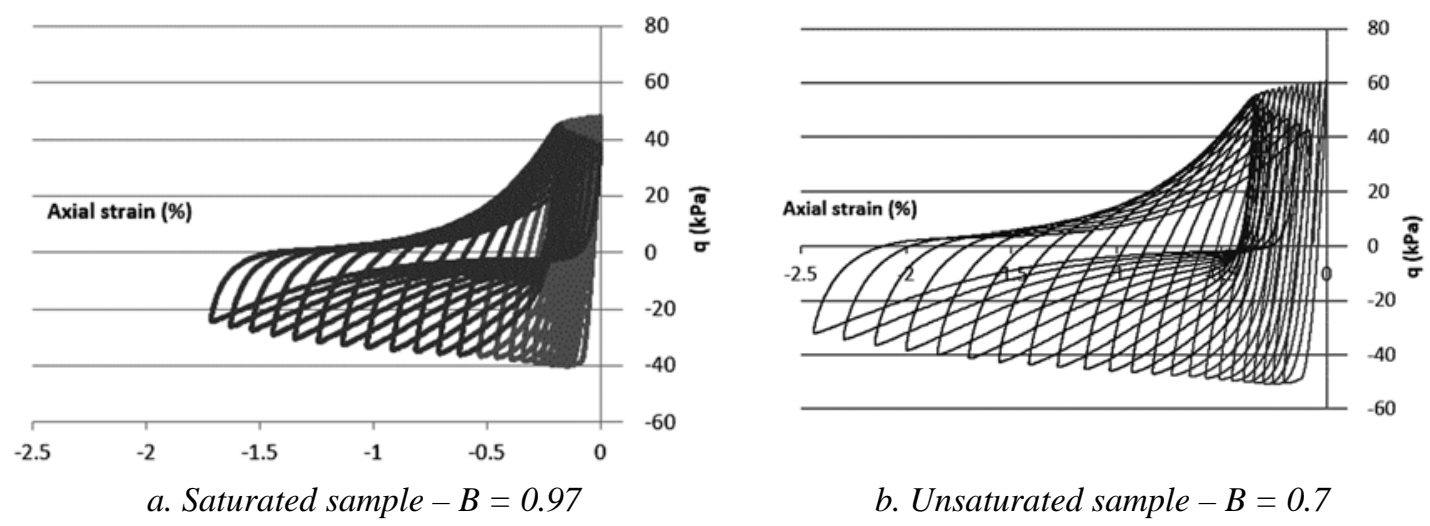

b. Unsaturated sample $-B=0.7$

Figure 6. Deviator stress versus axial strain. 


\section{XVİ̀mes Journées Nationales Génie Côtier - Génie Civil \\ Le Havre 2020}

Figure 7 shows the behavior characterizing for the cyclic mobility phenomenon. The curves are the butterfly form. The q-p' curve approaches the failure criteria lines and fluctuates, where $q$ is deviator stress and p' is effective mean stress. The slope of the failure criteria line can be calculated as equations (3) and (4). The lines achieved from the test corresponds to the angle $\emptyset_{\text {crit }}=37^{0}$.

$M=\frac{6 \cdot \sin \emptyset_{\text {crit }}}{3-\sin \emptyset_{\text {crit }}}$ (Compression)

$M=\frac{6 \cdot \sin \emptyset_{\text {crit }}}{3+\sin \emptyset_{\text {crit }}}$ (Extension)

Where $M$ is the slopes of the failure criteria lines and $\emptyset_{\text {crit }}$ is effective friction angle.

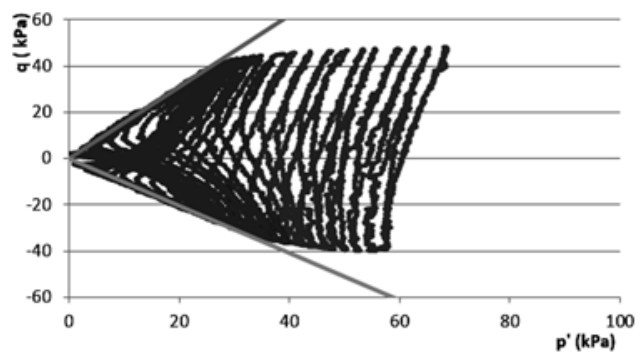

a. Saturated sample $-B=0.97$

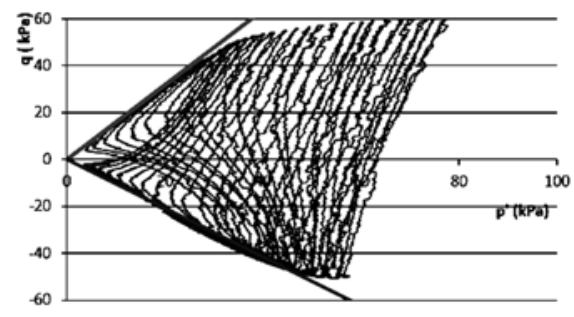

b. Unsaturated sample $-B=0.7$

Figure 7. Relationship between effective mean stress and deviator stress of the last load case for saturated and unsaturated samples.

\section{Conclusion}

This paper presents a laboratory study of liquefaction on RF Hostun sand in both saturated and unsaturated states. The result shows that although the sample is in the unsaturated state it can be liquefied when subjected to cyclic loading. The CSR needed to liquefy the sample increases when the saturation degree decreases.

When comparing the slope of failure criteria lines, it can be seen that the angles of these lines in both saturated and saturated test correspond to the effective friction angle of $37^{\circ}$. It suggests that the slopes of these lines do not depend on the saturation degree.

\section{References}

ARAB A., SADEK M., BENKHATIR M. (2016). Saturation effect on behavior of sandy soil under monotonic and cyclic loading: A laboratory investigation. Geotechnical and Geological Engineering, Vol. 34, pp 347-358. https://doi.org/10.1007/s10706-015-9949-6

BENAHMED N. (2001). Comportement mécanique d'un sable sous cisaillement monotone et cyclique : application aux phénomènes de liquéfaction et de mobilité cyclique. Thèse de doctorat. Ecole Nationale des Ponts et Chaussées, France.

CASTRO G. (1969). Liquefaction of sands. Harvard University, Cambridge. 


\section{Thème 4 - Ouvrages portuaires, offshore et de plaisance}

CHANEY R.C. (1978). Saturation effects on the cyclic strength of sands. Proceedings, Speciality Conference on Earthquake Engineering and Soil Dynamics, ASCE, Pasadena, Calif., 1, pp 342-358.

CHANEY R.C., PAMUKCU S. (1991). Earthquake effects on soil-foundation systems, Part II, Foundation Engineering Handbook, H.-Y. Fang Ed., pp 623-672.

FOURIE A., HOFMANN B., MIKULA R., LORD E., ROBERTSON P. (2001). Partially saturated tailings sand below the phreatic surface. Geotechnique, Vol. 51(7), pp 577-585. https://doi.org/10.1680/geot.2001.51.7.577

ISHIHARA K. (1993). Thirty third Rankine lecture: Liquefaction and flow failure during earthquakes. Géotechnique, Vol. 43(3), pp 351-451. https://doi.org/10.1680/geot.1993.43.3.351

IWASAKI T. (1986). Soil liquefaction studies in Japan (a state of art). Soil Dynamics and Earthquake Engineering, Vol. 5(1), pp 2-68. https://doi.org/10.1016/0267-7261(86)90024-2

JEFFERIES M., BEEN K. (2016). Soil liquefaction - a critical state approach. CRC press book. Taylor and Francis Group, 472 p. https://doi.org/10.1201/b19114

MARTIN G.R., FINN W.D.L., SEED H.D. (1978). Effects of system compliance on liquefaction tests. J Geotech Eng Div 104(4), pp 463-479

MULILIS J.P., TOWNSEND F.C., HORZ R.C. (1978). Triaxial testing techniques and sand liquefaction. ASTM STP 654 DynGeotech Test, pp 265-279. https://doi.org/10.1520/STP35681S

SASSA S., TAKAGAWA T. (2018). Liquefied gravity flow-induced tsunami: first evidence and comparison from the 2018 Indonesia Sulawesi earthquake and tsunami disasters. Journal of the International Consortium on Landslides, Vol 16, pp 195-200. https://doi.org/10.1007/s10346-018-1114-x

SEED H.B., IDRISS I.M. (1982). Ground motion and soil liquefaction during earthquake, Berkeley, University of California.

TSUKAMOTO Y., KAWABE S., MATSUMOTO J., HAGIWARA S. (2014). Cyclic resistance of two unsaturated silty sands against soil liquefaction. Soils and Foundations, Vol. 54(6), pp 1094-1103. https://doi.org/10.1016/j.sandf.2014.11.005

TRAN K.H., IMANZADEH S., TAIBI S., SOULI H., FLEUFEAU J.M., BOUCHEMELIA S., PANTET A. (2018a). Cyclic behavior of unsaturated Hostun sand. $4^{\text {th }}$ International Conference Unsaturated Soils \& Sustainable Construction UNSAT, Oran, Algeria.

TRAN K.H., IMANZADEH S., TAIBI S., SOULI H., FLEUFEAU J.M., PANTET A. (2018b). Some aspects of the cyclic behavior of quasi-saturated sand. $36^{\text {èmes }}$ Rencontres universitaires de Génie Civil de l'AUGC. France.

YOSHIMI Y., TANAKA K., TOKIMATSU, K. (1989). Liquefaction resistance of partially saturated sand. Soils and Found, Vol. 29(3), pp 157-162. https://doi.org/10.3208/sandf1972.29.3 157 